\title{
Socio-economic Factors as Predictors of Undergraduate Students' Attitude towards Entrepreneurship in Botswana
}

\author{
Som Pal Baliyan (Corresponding Author) \\ Department of Education Foundations, Faculty of Education, \\ University of Botswana, Gaborone, Botswana \\ E-mail: baliyansom@gmail.com \\ Pritika Singh Baliyan \\ Department of Accounting and Finance, Faculty of Business, \\ University of Botswana, Gaborone, Botswana \\ Email: psbaliyan@yahoo.com
}

Received: May 2, 2018

doi:10.5296/jebi.v5i1.13084
Accepted: May 28, 2018 Published: May 30, 2018

URL: http://dx.doi.org/10.5296/jebi.v5i1.13084

\begin{abstract}
Attitudes and values related to entrepreneurship imbibed by graduates may serve as impediments to future economic growth and development of entrepreneurship. Factors behind the nonchalant attitude towards entrepreneurship by the potential entrepreneur youth need to be identified and their influence remedied. This descriptive and co-relational study analyzed the socio-economic factors determining attitude towards entrepreneurship among graduates in Botswana. A valid and reliable questionnaire was used for data collection through a survey of $149(\mathrm{n}=149)$ randomly sampled graduates in Botswana. Data was analyzed through descriptive and inferential statistical tools of mean, frequency, independent t-test, one way analysis of variance and multiple regression analysis. Descriptive statistics indicated that the students would like to pursue their future career as entrepreneurs but opposite to the student career ambition, the parents want their children to become future professionals. Findings revealed that eight socio-economic factors namely; gender, program of study, year of study, mothers' education level, mothers' profession, family income level and students career ambition after completion of degree program and parents career ambition
\end{abstract}


after completion of degree program have significant influence on the students' attitude towards entrepreneurship. Multiple regression analysis indicated that the socio-economic factors are significant predictors of students' attitude towards entrepreneurship. Furthermore, mothers' education level was the top significant socio-economic factor predicting the students' attitude followed by students' career ambition after completion of the program, the year of study and the program of study. Further research can be conducted to investigate the reasons for gender difference in students' attitude towards entrepreneurship and, reasons for contradicting career ambitions of the students and their parents.

Keywords: Botswana, Entrepreneurial attitude, Demographic factors, Determinants of attitude, Graduates' perception

\section{Introduction}

The term entrepreneurship is elusive and, there is no clear and consistent definition. Entrepreneurship is "a way of thinking, reasoning and acting that is opportunity obsessed, holistic in approach, and leadership balanced" for the purpose of value creation. Holt (2003) views entrepreneurship as one of the four factors of economic development, the other three being land, capital and labour. Entrepreneurs are regarded as individuals who carry out new combinations, which come in different forms such as new goods or new quality products, new methods of production, new markets, new sources of supply or a new way of organisation (Nybakk \& Hansen, 2008). As they build their new ventures, and complete the job. They are disciplined, tenacious, and persistent, they are able to commit and recommit quickly, they are not intimidated by challenges, and they are bound to overcome hurdles, solve problems (Timmons \& Spinelli, 2009). Thus, entrepreneurs are viewed as drivers of economic development and growth because they change the current economic setup and create a new order in the socio-economic sphere. In this study the entrepreneur was used to refer to the owner or creator of a new business, small, growing, and successful business. This includes any person who sets up a small business, or changes from being an employee of an organisation to being self employed.

Entrepreneurship plays an important role in socio- economic growth and development and thus, recognized as the pivotal innovative instrument for socio-economic growth and stability in the countries (Kidane \& Harvey, 2009, Nafukko \& Muyia, 2010; Kavitha et al., 2013; Venkatachalam \& Waqif, 2005). Entrepreneurship brings a productive development in an economy and, rescue for the general unemployment in the economy of any nation (Teixeira \& Davey, 2008; Othman, Ghazali et al., 2005; Gurol \& Atsan, 2006; Movahedi, et al., 2013). Thus, militates against societal problems by increasing employment (Nybakk \& Hansen, 2008). Most studies have shown there is a positive relationship between entrepreneurship and economic growth in terms of job creation, firm survival and technological change (Gorman, et al. 1997; Lena and Wong 2003; Karanassios, Pazarskis et al., 2006). It is seen as an engine of economic progress, job creation and social adjustment (Yosof, et al., 2007). Thus, important role of entrepreneurship in society is widely acknowledged (Hisrich, Peterman, \& Kennedy, 2003). 
Universities play a functional role in promoting entrepreneurship to develop economy of society and country (Binks, Starkey et al., 2006; Co \& Mitchell, 2006). Universities are ideally considered the place in shaping entrepreneurial cultures and aspirations among students to survive in today's robust business milieu (Landstrom, 2005). Amiri and Moradi (2009) stated that universities prepare graduates for entrepreneurship but preparation should not be after graduating; it should happen during the study. Today entrepreneurship is offered in most of the universities as part of the curriculum but it is evident that levels of entrepreneurship are still not improving in the countries, particularly in the developing world (Herrington et al., 2009). There has been an upward trend in the number of youth entering higher education; this can be attributed to the high monetary benefits to education. Thousands of university graduates enter the job market very year, but the market capacity is not enough to hold the number of graduates (Sh et al., 2009). Graduate unemployment in Botswana has been rising very fast since 1995 along with national unemployment. The recent economic recession exacerbated the unemployment situation in the country. The labour market in the country is fully saturated, hence, the decision by the government to prioritize the development and support of small medium enterprises. Therefore, there is an option for the youths to be an entrepreneur which can not only pave a way of earning for themselves but also, to create jobs for other unemployed youths.

Considering the changing conditions of job market and society preference of jobs, many countries have placed intensive and frantic efforts and programmes towards development of entrepreneurship assisting graduates to be entrepreneurs and self-employed. In Botswana entrepreneurs are encouraged to establish their own venture with the intention to creation of wealth, economic growth and sustainable jobs lies in entrepreneurship. Developing countries such as Botswana, governments have emphasized self employment and entrepreneurship as a basic solution to the problem of unemployment situation in the country (Hoskin, Pour, \& Rzai, 2010). Financial institutions like Botswana Development Corporation (BDC) Citizen entrepreneurship Development Agency (CEDA), Local Enterprise Authority (LA) are assisting young entrepreneurs by providing financial and logistic support. Botswana Government is also encouraging young entrepreneurs through various schemes like Youth Development Fund (YDF), Young Farmers Fund (YFF) and so on so forth. Under target 20,000 the HRDC has taken initiative to prompt entrepreneurial skills among the Batswana youth by sponsoring unemployed youth to pursue Certificate and Diploma certificates in various vocational education Programs. Beside all these interventions from Government, Botswana is still ranked among the lowest among the countries in Africa.

Attitudes play a vital role in the life of a successful entrepreneur. Attitudes vary from one individual to another on factors influencing and, attractiveness of entrepreneurship as a career (Monitor, 2009). Guerrero et al. (2008) found that attitudes towards entrepreneurship are determining factors to decide to be an entrepreneur. The perspectives and believes of students attitude toward entrepreneurship are the results of their immediate social and cultural environment. Consequently, the orientation and conducts of youth and young graduates are affected by various individual and socio-ecological variables, which imply that the decision and desirability of becoming an entrepreneur or employee is a reflection of environmental 
and economic forces (Fayolle et al., 2006). Socio economic factors like parental profession, academic qualifications of parents and their attitude towards entrepreneurship have received considerable attention (Zampetakis \& Moustakis, 2006; Movahedi et al., 2013). Thus, entrepreneurship is a multifaceted endeavor that is affected by a variety of social, cultural, environmental, demographic and economic factors (Gurol \& Atson, 2006; Gaddam, 2007). Identification of factors influencing their attitude towards entrepreneurship can be one of the most important steps in identifying the barrier in entrepreneurship and self employment among graduates.

Schroeder and Rodermund (2006) reported that family background and educational background can predict different patterns of entrepreneurial interest development and therefore these factors also have a significant impact on development of an entrepreneurial attitude among the people. Other factors of gender, family experience with business and educational level found to have significant affect on entrepreneurial interests whereas family income status had no influence (Wang \& Wong, 2004). Ali et al. (2011) reported the mixed results on the impact of demographic factors on the entrepreneurial attitudes among potential entrepreneurs in six public sector Pakistani universities. There was no significant impact of gender, parents' education, parents' profession, residence on the entrepreneurial attitudes of the students at one university while, for other university, there was an impact of demographic variables such as parental education, parental income and profession (Ali et al., 2011). The understanding of attitude can be instrumental in assisting the policy direction and in encouraging entrepreneurship within the country (Acs et al., 2009). It is important to study a person tendencies or attitude is because human behavior is one of the major components which it can be judged and made decisions about the conduct or results (Akbari, Movahedi, $\&$ Kochekian, 2010). An investigation of pupils' attitudes towards entrepreneurs is important because these attitudes may reflect the prospect of becoming an entrepreneur themselves as a future career choice (Kolvereid, 1996; Guerrero et al., 2008).

\subsection{Problem Statement}

Botswana faces a serious challenge with its high level of unemployment among the youth due to saturation of job, relevant experience, poor skills, education levels and more importantly attitude towards entrepreneurship. The daunting observation is that while the graduate labour force is on the rise, a large number of graduates possessing diplomas and degrees are finding it difficult to find employment. Considering the important role of entrepreneurship in the socio- economic development of the people and the country, Botswana government initiated rigorous efforts and programmes encouraging youths to establish their own venture with the intention to creation of wealth, economic growth and sustainable jobs lies in entrepreneurship, but did help to rescue the situation. Attitudinal disposition towards entrepreneurship among students may be influenced by various socio-economic factors. Though such variables cannot be manipulated to bring about desirable changes in the attitude of students towards entrepreneurship, an environment created with these variables can still be manipulated. A better understanding of the attitudes and perceptions towards entrepreneurship in Botswana will enable role players to evaluate, reinforce and to change strategy in order to enhance entrepreneurial behaviour in the country contributing to economic development, wealth 
creation and the alleviation of poverty. Therefore, it is vital to analyze and understand the determinants of attitude of youths towards entrepreneurship in the country.

\subsection{Aim and Objectives of the Study}

The aim of the study was to investigate the influence of socio-economic factors on the undergraduate students' attitudes towards entrepreneurship in Botswana. The specific objectives of this study were:

i) To describe the socio-economic factors of the students involved in the study.

ii) To determine the influence of socio-economic factors on the attitude of students' towards entrepreneurship.

iii) To determine the socio-economic factors as predictors of students' attitudes towards entrepreneurship.

\section{Methodology}

A descriptive and co-relational research design was adopted for this quantitative study. The research design of this study is based on the model in which the socio-economic variables were independent variables or predictors, and student's attitude towards entrepreneurship was the dependent variable. A survey was conducted to collect the relevant data as the survey is the best method to explore the facts. The target population consisted of undergraduate students studying at Botswana University of Agriculture and Natural Resources, Gaborone, Botswana. A total of 149 students $(n=149)$ undergraduates enrolled in different agricultural programs were randomly sampled.

Based on the review of literature, a valid and reliable questionnaire was constructed as the instrument for data collection. The first part of the questionnaire was designed to obtain information on socio-economic factors of the students which contained eleven (11) items namely; gender, location of residence, program of study, year of study, mothers' level of education, fathers' level of education, mothers' profession, fathers' profession, family income, students' career ambition after completion of degree and, parents' career ambition after completion of degree. The second part of the instrument composed of twelve (12) items measuring the students' attitude towards entrepreneurship. The attitude items were measured on a four point Likerts' scale categories (Likert, R., 1977): Strongly Agree (SA) = 4, Agree $(A)=3$, Disagree $(D)=2$ and Strongly Disagree $(S D)=1$. Likerts' scale has been the most popular technique to measure the attitude (Fabrigar et al., 2005). Content and face validity of the instrument was established by a five member panel of experts from education and educational research. The reliability analysis was conducted to determine the degree of the instrument's reliability. Cronbach's alpha reliability coefficient of the twelve items measuring the students' attitude towards entrepreneurship was found to be 0.836 . A reliability level of .70 is acceptable for the instrument to be reliable (Creswell, 2013; Saunders, Lewis, \& Thornhill, 2012; Field, 2009) and therefore, the instrument and data collected was found suitable for further analysis. 


\section{Macrothink}

The data were analysed using the SPSS 23 version of the software package whereby descriptive and inferential statistics were employed. Descriptive statistics was used to analyze the socio-economic factors whereby frequency and percentages of these factors were calculated. One way analysis of variance (ANOVA) was employed to determine the influence of socio-economic variables on the attitude of students towards entreprenurship. A multiple regression analysis was used to predict the students' attitudes towards entrepreneurship. For ANOVA and regression analyses, the score of students' attitude towards entrepreneurship and, the students' socio-economic variables were considered as the dependent variable and the independent variables, respectively.

\section{Results and Discussion}

The findings of the study are presented and discussed in the following sections.

\subsection{Socio-Economic Factors of Students}

The first objective of this study was to describe the socio-economic factors of the students involved in the study. The study used eleven (11) demographic factors of the students namely; gender, location of residence, program of study, year of study, mothers' level of education, fathers' level of education, mothers' profession, fathers' profession, family income, students' career ambition after completion of degree and parents' career ambition after completion of degree. The information on socio-economic factors collected from the students was analyzed through descriptive statistical tools of frequency and percentage. The descriptive statistics of socio-economic variables analyses are presented in Table 1.

Table 1. Frequency and percentage of the socio-economic factors of students $(n=149)$

\begin{tabular}{|c|c|c|c|}
\hline Variable & Variable Level & $\mathrm{f}$ & $\%$ \\
\hline \multicolumn{4}{|l|}{$\begin{array}{l}\text { Gender } \\
\text { respondents }\end{array}$} \\
\hline & Male & 48 & 32.2 \\
\hline & Female & 101 & 67.8 \\
\hline \multicolumn{4}{|l|}{$\begin{array}{l}\text { Location } \\
\text { residence }\end{array}$} \\
\hline & Rural & 50 & 33.6 \\
\hline & Urban & 81 & 54.4 \\
\hline & Peri-Urban & 18 & 12.1 \\
\hline \multicolumn{4}{|l|}{ Program of study } \\
\hline & $\begin{array}{l}\text { Agricultural } \\
\text { economics }\end{array}$ & 39 & 26.2 \\
\hline & $\begin{array}{l}\text { Agricultural } \\
\text { education }\end{array}$ & 21 & 14.1 \\
\hline & $\begin{array}{l}\text { Agricultural } \\
\text { extension }\end{array}$ & 18 & 12.1 \\
\hline & Others & 71 & 47.7 \\
\hline \multicolumn{4}{|l|}{ Level of study } \\
\hline & Year 2 & 56 & 37.6 \\
\hline & Year 3 & 38 & 25.5 \\
\hline & Year 4 & 55 & 36.9 \\
\hline \multicolumn{4}{|l|}{$\begin{array}{l}\text { Mothers' level of } \\
\text { education }\end{array}$} \\
\hline & No education & 15 & 10.1 \\
\hline
\end{tabular}




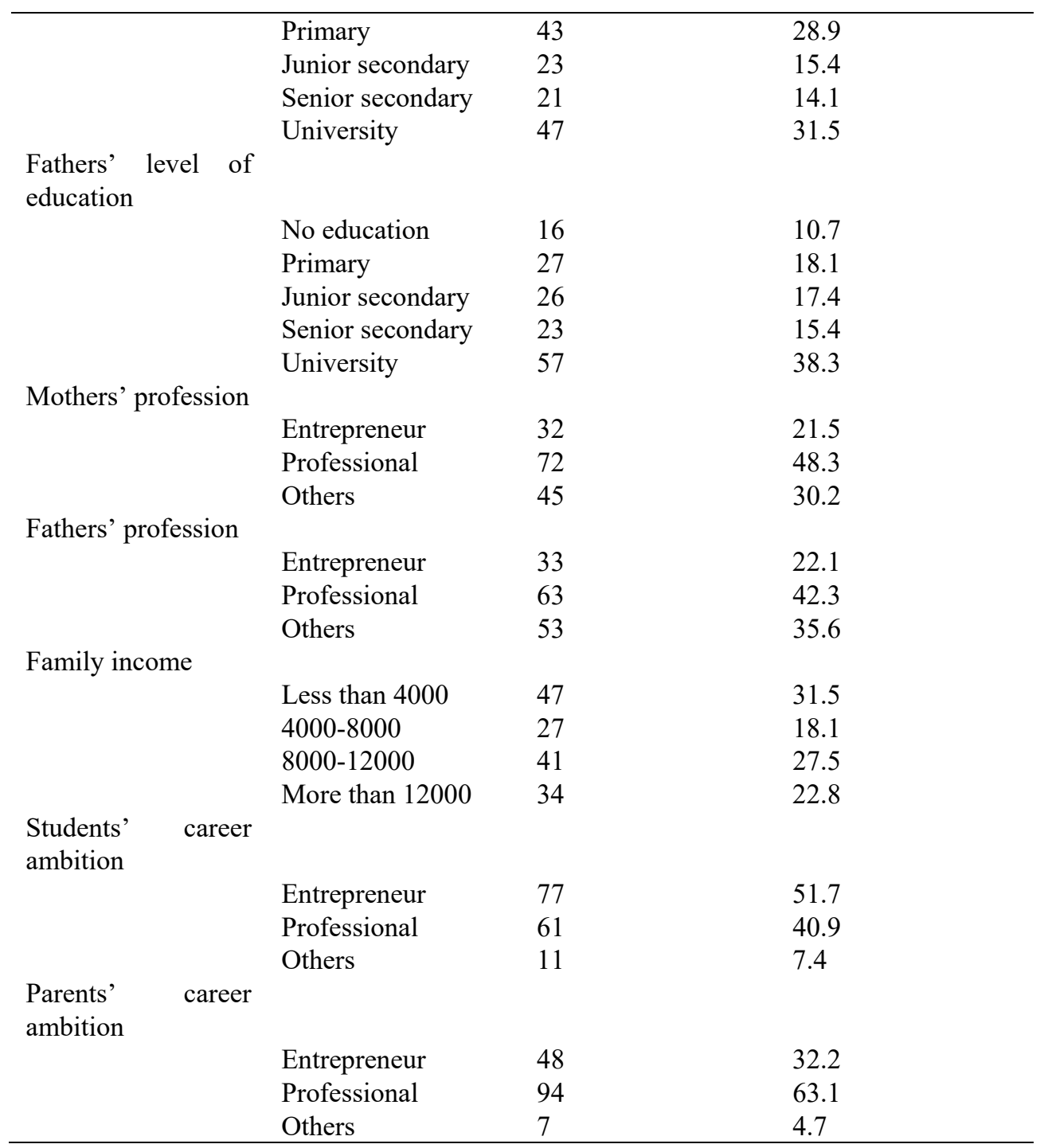

Table 1 indicated that among the sampled students, about one third students were male $(32.2 \%)$ and remaining two third (67.8\%) were female students. It indicated that female students preferred studying in agricultural programs as compared to the male students. A higher percentage of sampled students $(54.4 \%)$ was staying in the urban areas followed by $33.8 \%$ staying in the rural areas. Only $12.1 \%$ students were staying in the peri urban areas.

A higher proportion of the students $(26.2 \%)$ were studying for agricultural economics program followed by agricultural education program $((14.1 \%)$. It reflects that the most preferred program by the students is agricultural economics which is an entrepreneurship oriented program. Also, indicates their good attitude towards entrepreneurship. However, about half of the sampled students (47.7\%) were studying for various other programs which were not specifically identified in this study. More than two third of the sampled students were either studying in the second year $(37.6 \%)$ or in the fourth year $(36.9 \%)$ of their programs. The year one students were not involved in this study assuming that they are new in the programs and therefore, they may not provide reliable information on their attitude towards entrepreneurship.

Comparing the parental educational level, almost equal percentage (10\%) of fathers and 
mothers had no education at all. Only $31.5 \%$ mothers have obtained university education whereas $38.3 \%$ of fathers obtained university education. It indicated that the fathers were more qualified in terms of the university education than the mothers. Therefore, it can be said that mothers are still behind than the fathers as far as parental education level is concerned.

About $22 \%$ of the mothers and fathers were entrepreneurs indicated that the parents did not differ in their profession as an entrepreneur. However, mothers were higher in professional jobs $(48.3 \%)$ as compared with the fathers $((42.3 \%)$. The family income levels of the students indicate that majority of students $(58.3 \%)$ belong to the high income level (above P9000) whereas a lowest of $3.8 \%$ students belongs to the low income families (less than P3000).

A majority of the students (51.7\%) intend to be entrepreneurs in future while $40.9 \%$ of the students had ambition to become professionals after completion of their program. It indicated that the students are inclined to be entrepreneur in their future. This finding is similar to the findings of Kabui and Maalu, 2012) who found that majority of the students indicated that they would like to pursue their career in entrepreneurship after completing school. Opposite to the student career ambition, the majority of the parents $(63.1 \%)$ want their children to become professionals in their future. In other words, it reflected that the parents do not want their children to become entrepreneur in their future. It can be vital and interesting to investigate and unveil the facts behind the contradicting career ambitions of the students and their parents which may lead to formulation of the appropriate policies towards the entrepreneurial development in the country.

\subsection{Influence of Socio-Economic Variables on the Students' Attitudes towards Entrepreneurship}

The second objective of this study was to determine the influence of socio-economic factors on the attitude of students' towards entrepreneurship. In this study, there were two type of independent variables (socio-economic factors); dichotomous and discrete variables. An independent t-test statistical analysis was done when the levels of the independent variables were with two categories and, one-way analysis of variance was performed when the levels of the independent variable was more than two.

\subsubsection{Influence of Dichotomous Socio-economic Factors on Students' Attitude}

An independent t-test analysis was employed to determine the influence of gender as a dichotomous nature of independent variable. The results of the independent t-test are presented in Table 2. The gender of the students showed significant influence on students' attitude towards entrepreneurship $(\mathrm{t}=-4.065, \mathrm{p}=.000)$. Further, female students had more influence on the attitude towards entrepreneurship $(\overline{\mathrm{x}}=31.92)$ as compare to the influence of male students $(\overline{\mathrm{x}}=28.21)$. This finding is contradicting the findings of Delmar and Davidson, (2000) and; Matthews and Moser (1995) who determined that males have a higher preference for entrepreneurship behavior than females. There may be reasons as to why the female students are more inclined towards entrepreneurship than the male students and, which can be revealed through a further study. 


\section{Macrothink}

Table 2. Independent t-test of the Influence of Respondents' Socio-economic Factors on Attitude towards Entrepreneurship ( $d f=149)$

\begin{tabular}{llllllll}
\hline Variable & Level & $\mathrm{n}$ & $\overline{\mathrm{x}}$ & $\mathrm{SD}$ & $\mathrm{SE}$ & t-value & Sig. \\
\hline Gender & Male & 48 & 28.21 & 2.67 & .38 & $-4.065^{*}$ & .000 \\
& Female & 101 & 31.92 & 6.04 & .60 & & \\
\hline
\end{tabular}

$p<.05$.

\subsubsection{Influence of Discrete socio-economic Variables on Students' Attitude}

One way analysis of variance (ANOVA) was employed to investigate the influence of discrete type of socio-economic variables on the attitude of students towards entrepreneurship. Socio-economic variables of students and, the score of students' attitude towards entrepreneurship were considered as the independent and dependent variables, respectively. The results of analysis of variance are presented in Table 3 which indicated that out of ten (10) discrete socio-economic variables only seven (7) variables have significant influence on the students' attitude towards entrepreneurship. These seven significant socio-economic variables included; program of study $\mathrm{F}(3,145)=9.51, \mathrm{p}=.000)$, year of study $\mathrm{F}(2,146)=21.76$, $\mathrm{p}$ $=.000)$, mothers' level of education $\mathrm{F}(4,144)=8.08, \mathrm{p}=.000)$, mothers' profession $\mathrm{F}(2,146)$ $=5.51, \mathrm{p}=.005)$, family income level $\mathrm{F}(3,145)=8.42, \mathrm{p}=.000)$, students career ambition after completion of degree program $\mathrm{F}(2,146)=7.12, \mathrm{p}=.000)$ and, parents career ambition after completion of degree program $\mathrm{F}(2,146)=8.80, \mathrm{p}=.000)$.

Table 3. One-way Analysis of Variance (ANOVA) and Post Hoc Test of the Influence on respondents' attitude towards entrepreneurship by discrete nature socio-economic factors

\begin{tabular}{lcccccc}
\hline Variable & $\mathrm{n}$ & $\overline{\mathrm{x}}$ & $\mathrm{SD}$ & $\mathrm{SE}$ & $\mathrm{F}$ & Sig. \\
\hline Location of residence & & & & & 2.15 & .120 \\
Rural & 50 & 31.68 & 5.68 & .80 & & \\
Urban & 81 & 30.60 & 5.68 & .63 & & \\
Peri-Urban & 18 & 28.61 & 2.83 & .66 & & \\
Program of study & & & & & 9.51 & $.000^{*}$ \\
Agricultural economics & 39 & 32.79 & 5.97 & .95 & & \\
Agricultural education & 21 & 33.80 & 6.65 & 1.45 & & \\
Agricultural extension & 18 & 31.44 & 5.18 & 1.22 & & \\
Others & 71 & 28.49 & 3.79 & .45 & & \\
Year of study & & & & & 21.76 & $.000^{*}$ \\
Year 2 & 56 & 29.23 & 4.12 & .55 & & \\
Year 3 & 38 & 28.05 & 2.65 & .42 & & \\
Year 4 & 55 & 34.09 & 6.41 & .86 & & \\
Mothers' level of education & & & & & 8.08 & $.000^{*}$ \\
No education & 15 & 32.53 & 5.05 & 1.30 & & \\
Primary & 43 & 33.86 & 6.32 & .96 & & \\
Junior secondary & 23 & 30.26 & 5.04 & 1.05 & & \\
Senior secondary & 21 & 28.55 & 1.82 & .40 & & \\
& & & & & & \\
\hline
\end{tabular}




\section{MlMacrothink}

University

Fathers' level of education

No education

Primary

Junior secondary

Senior secondary

University

Mothers' Profession

Entrepreneur

Professional

Others

Fathers' Profession

Entrepreneur

Professional

Others

Family income (Pula/month)

Less than 4000

4000-8000

8000-12000

More than 12000

Students' career ambition after completion of degree

Entrepreneur

Professional

Others

Parents' career ambition after completion of degree

Entrepreneur

Professional

Others $\begin{array}{llll}47 & 28.38 & 4.56 & .66\end{array}$

1.86

.120

$\begin{array}{llll}16 & 29.18 & 3.85 & .96\end{array}$

$\begin{array}{llll}27 & 30.40 & 5.14 & .99\end{array}$

$\begin{array}{llll}26 & 33.11 & 6.22 & 1.22\end{array}$

$\begin{array}{llll}23 & 31.13 & 5.48 & 1.14\end{array}$

$\begin{array}{llll}57 & 30.05 & 5.47 & .72\end{array}$

$\begin{array}{llll}32 & 29.03 & 4.93 & .87\end{array}$

$\begin{array}{llll}72 & 32.20 & 5.93 & .70\end{array}$

$\begin{array}{llll}45 & 29.55 & 4.43 & .66\end{array}$

$2.36 \quad .098$

$\begin{array}{llll}33 & 32.06 & 6.61 & 1.15\end{array}$

$\begin{array}{llll}63 & 29.67 & 4.85 & .61\end{array}$

$\begin{array}{llll}53 & 31.15 & 5.26 & .72\end{array}$

$8.42 \quad .000 *$

$\begin{array}{llll}47 & 29.23 & 4.20 & .61\end{array}$

$\begin{array}{llll}27 & 34.14 & 5.94 & 1.14\end{array}$

$\begin{array}{llll}41 & 32.02 & 5.61 & .87\end{array}$

$\begin{array}{llll}34 & 28.50 & 4.87 & .83\end{array}$

$7.12 \quad .000 *$

$\begin{array}{llll}77 & 29.96 & 5.11 & .64\end{array}$

$\begin{array}{llll}61 & 29.87 & 4.68 & .65\end{array}$

$\begin{array}{llll}11 & 37.27 & 4.64 & 1.40\end{array}$

$8.80 \quad .000 *$

$\begin{array}{llll}48 & 29.03 & 5.86 & .94\end{array}$

$\begin{array}{llll}94 & 32.48 & 4.08 & .44\end{array}$

$\begin{array}{llll}7 & 36.85 & 5.61 & 2.12\end{array}$

$* p<.05$.

Given the overall significant influences of program of study, year of study, mothers' level of education, mothers' profession, family income level, students' career ambition after completion of degree program and, parents career ambition after completion of degree program on the students' attitude towards entrepreneurship, least square significant (LSD) post-hoc analyses were done. A summary of the Post Hoc test is also included in Table 3.

Table 3 indicated that the sstudents studying in agricultural education program had higher influence $(\overline{\mathrm{x}}=33.80)$ on the students' attitude towards entrepreneurship as compare to other programs of their study. It indicated the need to determine the factors responsible for such influence. Further, the final year of the study for their programs had higher influence on their attitude towards entrepreneurship $(\overline{\mathrm{x}}=34.09)$ as compare to other years of the study.

Mothers with primary level of education had significantly more influence $(\overline{\mathrm{x}}=33.86)$ followed by junior level of education $(\overline{\mathrm{x}}=30.26)$, senior level of education $(\overline{\mathrm{x}}=28.55)$ and 
university level of education $(\overline{\mathrm{x}}=28.38)$ on students' attitude towards entrepreneurship (Table $3)$. It indicated that lower the mother's level of education, higher the influence on the students attitude towards entrepreneurship. Professional mothers had higher influence on the students' attitude $(\overline{\mathrm{x}}=32.20)$ than the mothers with others profession $(\overline{\mathrm{x}}=29.55)$ and the entrepreneurship as their profession $(\overline{\mathrm{x}}=29.03)$. It reflects that mothers would like their children to be professional rather than an entrepreneur.

Medium income levels of the family (P4000 - P8000) and (P8000 - P12000) have more influence on the students' attitude $(\overline{\mathrm{x}}=34.14)$ and $(\overline{\mathrm{x}}=32.02)$, respectively than the low income $(<4000)$ and high income levels $(\mathrm{P}>12000)$ with the mean of influence of $(\overline{\mathrm{x}}=44.95)$ and $(\overline{\mathrm{x}}=44.95)$, respectively (Table 3 ). It is therefore concluded that medium the income levels, higher the influence on the attitude of students towards entrepreneurship. Further, high and low income levels had less influence than the medium income levels. This finding call for a further research to unveil if the low and high income has positive or negative influence on the students attitude towards entrepreneurship.

Table 3 also highlighted that the entrepreneurship as the students' career ambition after completion of their degree program had higher influence $(\bar{x}=29.96)$ on the students' attitude than the professional as the students' career ambition $(\overline{\mathrm{x}}=29.87)$ and the other career ambitions $(\bar{x}=37.27)$. It indicated that the students are more interested to be an entrepreneurial rather than a professional in their future career. Professional as the parents career ambition after completion of degree program had higher influence $(\overline{\mathrm{x}}=32.48)$ on the students' attitude than the entrepreneurship career ambitions $(\overline{\mathrm{x}}=29.03)$. It indicated that the parents of the students are more interested to see their children as a professional rather than an entrepreneur in their future career. This finding is similar of Kabui, and Maalu (2012) who found that the students who had either parent in self employment, majority of them indicated that they would not be motivated into business. The interpretation here was that their personal experiences in their parents businesses may have influenced their perception of success in those specific lines of business. However, the finding of this study indicated a contradiction between the ambition of the students and the ambition of their parents and therefore, a further study investigating the reasons for such differences is recommended.

\subsection{Prediction of Students'Attitudes towards Entrepreneurship}

The third objective of the study was to determine the socio-economic factors as predictors of students' attitudes towards entrepreneurship. The Enter method of multiple regression analysis was performed to predict the students' attitudes from their socio-economic variables. The students' socio-economic factors were considered as independent variables and, the scores of students' attitude items were treated as the dependent variable. Table 4 presented the results of the multiple regression analysis which indicated that the socio-economic factors are statistically significant predictors of students' attitude towards entrepreneurship $\mathrm{F}(11,137)=$ $8.29, \mathrm{p}=<.001)$. This means that the eleven socio-economic factors of students significantly predict their attitude towards entrepreneurship.

The total variance of prediction of students' attitude towards entrepreneurship explained by this regression model was 40 percent (Table 4). It indicated that the multiple regression 
model of all the eleven factors explained only 40 percent of the variance in students' attitude. This result indicates that there are some other observable and latent socio-economic variables which might explain the remaining large portion of variance $(60 \%)$ in students' attitude towards entrepreneurship. Therefore, further researcher is recommended focusing on wider range of socio-economic factors predicting the students' attitude towards entrepreneurship.

Table 4. Regression analysis of socio-economic factors predicting students' attitude towards entrepreneurship

\begin{tabular}{llllll}
\hline Source & SS & df & MS & F & Sig. \\
\hline Regression & 1774.50 & 11 & 161.32 & 8.29 & $.000^{*}$ \\
\hline Residual & 2663.21 & 137 & 19.44 & & \\
Total & 4437.71 & 148 & & & \\
\hline
\end{tabular}

$* p<.05$, Multiple $\mathrm{R}=.632, \mathrm{R}$-square $=.400$.

Table 5 presents the regression coefficients reflecting the relative importance of the socio-economic factors (independent variables) in predicting the students' attitude towards entrepreneurship.

Table 5. Regression Coefficients of the socio-economic factors variables predicting students' attitude towards entrepreneurship

\begin{tabular}{|c|c|c|c|}
\hline Independent variables & Beta & t value & Sig. \\
\hline Constant & ---- & 10.413 & .000 \\
\hline Gender & .088 & 1.159 & .249 \\
\hline Location of residence & -.133 & -1.866 & .064 \\
\hline Program of study & -.175 & -2.351 & $.020^{*}$ \\
\hline Year of study & .211 & 2.587 & $.011^{*}$ \\
\hline $\begin{array}{l}\text { Mothers' level of } \\
\text { education }\end{array}$ & -.369 & -3.658 & $.000^{*}$ \\
\hline $\begin{array}{l}\text { Fathers' level of } \\
\text { education }\end{array}$ & .163 & 1.954 & .059 \\
\hline Mothers' Profession & -.035 & -.478 & .634 \\
\hline Fathers' Profession & -.050 & -.675 & .501 \\
\hline Family income & .117 & 1.412 & .160 \\
\hline $\begin{array}{l}\text { Students' career } \\
\text { ambition }\end{array}$ & .221 & 2.753 & $.007^{*}$ \\
\hline $\begin{array}{l}\text { Parents' career } \\
\text { ambition }\end{array}$ & .016 & .210 & .834 \\
\hline
\end{tabular}

Observing the significance of the eleven socio-economic factors, only four factors namely; the program of study $(\mathrm{t}=-2.351, \mathrm{p}=.020)$, year of study $(\mathrm{t}=2.587, \mathrm{p}=.011)$, mothers education level $(\mathrm{t}=-3.658, \mathrm{p}=.000)$ and, students career ambition after completion of the program $(t=2.753, p=.007)$ were the significant predictors of the students attitude towards 
entrepreneurship (Table 5). The rank order of the significant predicting variables indicates that mothers' education level is the most important significant socio-economic factor predicting the students' attitude of students towards entrepreneurship followed by students' career ambition after completion of the program and the year of study. The program of the study had the least significant influence on the students' attitude towards entrepreneurship.

\section{Conclusion and recommendations}

The findings of this study have led to the conclusions and recommendations as follows.

Descriptive statistics the socio-economic factors indicated that a higher percentage of sampled students were staying in the urban areas followed by the rural areas. Among the sampled students, about one third were male and the remaining two third were female students. It was also concluded that mothers are behind than the fathers as far as overall parental education level is concerned. Although mothers' of students were in higher numbers in professional jobs as compared to the fathers, they were equally engaged in entrepreneurial profession. Majority of the students belong to the high income families whereas the lowest proportion of students belongs to the low income families. A majority of the students were ambitious to become entrepreneur in their future but, contrarily, majority of the parents want their children to become professionals rather than entrepreneur.

Eight socio-economic factors of students that have significant influence on the students' attitude towards entrepreneurship included gender, program of study, year of study, mothers' level of education, mothers' profession, family income level, students career ambition after completion of degree program and parents career ambition after completion of degree program. Furthermore, it was found that lower level of mother's education has higher influence on the students' attitude towards entrepreneurship. Professional mothers had higher influence on the students' attitude than the mothers with others professions. It was concluded that medium level of family income has higher influence on the attitude of students towards entrepreneurship. As the students' career ambition to become entrepreneur had higher influence on the students' attitude than the professional, it was concluded that the students are more interested to be an entrepreneurial rather than becoming professional in their future career. On the other hand, the parents of the students are more ambitious to see their children in becoming professional rather than an entrepreneur in their future.

Only four of the socio-economic factors of the students namely; program of study, year of study, mothers' level of education and, students career ambition after completion of degree program were determined as the significant predictors of the students' attitude towards entrepreneurship. Furthermore, mothers' level of education followed by the students' career ambition after completion of degree program were the top two significant predictors of the students' attitude towards entrepreneurship followed by the year of study and the program of study.

\section{Recommendations for Further Research}

Further similar research should include more observable and latent socio-economic variables influencing students' attitudes towards entrepreneurship. A study can be conducted to 
investigate and unveil the facts behind the contradicting future career ambitions of the students and their parents. The female students are more inclined towards entrepreneurship than the male students therefore, the reasons for such inclination (gender difference) towards entrepreneurship can be revealed through a further study. Further studies investigating facts so as to how and why the mothers' level of education and the students' career ambition factors influence the students' attitude towards entrepreneurship.

\section{References}

Acs, Z. J., Amorós, J. E., Bosma, N. S., \& Levie, J. (2009). From entrepreneurship to economic development: Celebrating ten years of Global Entrepreneurship Monitor. Frontiers of Entrepreneurship Research, 29(16), 1.

Akbari, R., Movahedi, R., \& Kochekian, H. (2010). Examining Attitude of Agricultural Students towards Employment in Agricultural Sector (Case Study: Bu-Ali Sina University), Journal of Agricultural Extension and Education Research, 2(4), 91-102.

Ali, A., Keith, J., Topping, K. J., \& Tariq, R. H. (2011). Entrepreneurial Attitudes among Potential Entrepreneurs. Pakistan Journal of Commerce and Social Science, 5(1), 12-46.

Amiri, A., \& Moradi, Y. (2009). The Survey of Entrepreneurial Attitudes Barriers of Students. Quarterly Journal of Research and Planning in Higher Education, 14(3), 45-67.

Creswell, J. (2013). Research design: Qualitative, quantitative, and mixed methods approaches (4th ed.). Thousand Oaks, CA: Sage.

Dioneo-Adetayo, E. A. (2006). Factors influencing attitude of youth towards entrepreneurship. International Journal of Adolescence and Youth, 13(1-2), 127-145. https://doi.org/10.1080/02673843.2006.9747970

Fabrigar L. R., MacDonald T. K., \& Wegener D. T. (2005). The structure of attitudes. In D. Albarracin, B. T. Johnson, \& M. P. Zanna (Eds.), The handbook of attitudes (pp.79-103). Mahwah, NJ: Lawrence Erlbaum Associates.

Fayolle, A., Gailly, B., \& Lassas-Clerc, N. (2006). Effect and counter-effect of entrepreneurship education and social context on student's intentions. Estudios de economía aplicada, 24(2), 509-523.

Field, A. (2009). Discovering statistics using SPSS (3rd ed). Sage Publications: London.

Gaddam, S. (2007). A conceptual analysis of factors influencing entrepreneurship behavior and actions. ICFAI Journal of Management Research, 6(11), 46-63.

Gorman, G., Hanlon, D., \& King, W. (1997). Some research perspectives on entrepreneurship education, enterprise education and education for small business management: A ten-year literature review. International Small Business Journal, 15(3), 56-77. https://doi.org/10.1177/0266242697153004

Guerrero, M., Rialp, J., \& Urbano, D. (2008). The impact of desirability and feasibility on entrepreneurial intentions: A structural equation model. International Entrepreneurship and 
Management Journal, 4(1), 35-50. https://doi.org/10.1007/s11365-006-0032-x

Gürol, Y., \& Atsan, N. (2006). Entrepreneurial characteristics amongst university students: Some insights for entrepreneurship education and training in Turkey. Education and Training, 48(1), 25-38. https://doi.org/10.1108/00400910610645716

Herrington, M., Kew, J., Kew, P., \& Monitor, G. E. (2010). Tracking entrepreneurship in South Africa: A GEM perspective. South Africa: Graduate School of Business, University of Cape Town.

Karanassios, N., Pazarskis, M., Mitsopoulos, K., \& Christodoulou, P. (2006). EU strategies to encourage youth entrepreneurship: Evidence from higher education in Greece. Industry and Higher Education, 20(1), 43-50. https://doi.org/10.5367/000000006776150747

Kavitha, R., Anantharaman, R. N., \& Ramanathan, S. (2013). Environmental, personality and motivational factors; comparism study between entrepreneurs and women non entrepreneurs in Malaysia. International Journal of Business and Management, 8(13).

Kidane, A., \& Harvey, B. H. (2009). Profile of entrepreneurs: Employing stepwise regression analysis to determine factors that impact success of entrepreneurs. Review of Business Research, 9(3), 55-65.

Kolvereid, L. (1996). Prediction of employment status choice intentions. Entrepreneurship Theory and practice, 21(1), 47-58. https://doi.org/10.1177/104225879602100104

Landstrom, H. (2007). Pioneers in entrepreneurship and small business research (Vol. 8). Springer Science \& Business Media.

Lee, L., \& Wong, P. K. (2003). Attitude towards entrepreneurship education and new venture creation. Journal of Enterprising Culture, 11(04), 339-357. https://doi.org/10.1142/S0218495803000111

Lee, S. M., Chang, D., \& Lim, S. B. (2005). Impact of entrepreneurship education: A comparative study of the US and Korea. The International Entrepreneurship and Management Journal, 1(1), 27-43. https://doi.org/10.1007/s11365-005-6674-2

Likert, R. 1977. A technique for the measurement of attitudes. In G. F. Summers (Ed.), Attitude measurement (p.149-158). London: Kershaw Publishing Company.

Monitor, G. E. (2014). GEM 2013 global report. Global Report.

Movahedi, R., Latifi, S., \& Sayyar, L. Z. (2013). The factors affecting agricultural students' attitude towards self-employment and entrepreneurship. International Journal of Agriculture and Crop Sciences, 5(16), 1813.

Nafukko, F.M. \& Helen Muyia, M.A. (2010). Entrepreneurship and socioeconomic development in Africa: A reality or myth? Journal of European Industrial training, 3(2), 96 109. https://dx.doi.org/10.1108/03090591011102961

Nybakk, E., \& Hansen, E. (2008). Entrepreneurial attitude, innovation and performance 


\section{Macrothink}

among Norwegian nature-based tourism enterprise. Forestry Policy and Economics, 10(7-8), 473-479. https://doi.org/10.1016/j.forpol.2008.04.004

Othman, M. N., Ghazali, E., \& Cheng, O. C. (2005). Demographics and personal characteristics of urban Malaysian entrepreneurs: An ethnic comparison. International Journal of Entrepreneurship and Innovation Management, 5(5-6), 421-440. https://doi.org/10.1504/IJEIM.2005.006997

Peterman, N., \& Kennedy, J. (2003). Enterprise education: influencing students' perception of entrepreneurship. Entrepreneurship Theory and Practice, 28(4), 129-141. https://doi.org/10.1046/j.1540-6520.2003.00035.x

Sh, B., Athari, Z., \& Zarafshni, K. (2009). Survey of agricultural scientific-applied student tendency to entrepreneurship (case study: Kermanshah Province). Journal of Entrepreneurship Development, 2(6), 73-95.

Teixeira A. A. C., \& Davey, T. (2008). Attitudes of Higher Education students to new venture creation: A preliminary Approach to the Portuguese Case. Lusa.

Timmons, J. A., \& Spinelli, S. (2009). New venture creation entrepreneurship for the 21st Century (8th ed.). Boston, MA: McGraw-Hill.

Venkatachalam, V. B., \& Waqif, A. A. (2005). Outlook on integrating entrepreneurship in management education in India. Decision, 32(2), 57-71.

Yusof, M., Sandhu, M. S., \& Jain, K. K. (2007). Relationship between psychological characteristics and entrepreneurial inclination: A case study of students at University Tun Abdul Razak (Unitar). Journal of Asia Entrepreneurship and Sustainability, 3(2), 1.

\section{Copyright Disclaimer}

Copyright for this article is retained by the author (s), with first publication rights granted to the journal.

This is an open-access article distributed under the terms and conditions of the Creative Commons Attribution license (http://creativecommons.org/licenses/by/3.0/). 